\title{
直階段から地下空間へ流入する流量の評価 に関する実験的研究 \\ EXPERIMENTAL STUDY ON THE EVALUATION ON DISCHARGE OF INUNDATING WATER FLOWED OVER STRAIGHT STAIR TO UNDERGROUND SPACE
}

\author{
多田彰秀 $1 \cdot$ 井上啓由 ${ }^{2} \cdot$ 本田洋平 ${ }^{3} \cdot$ 古本勝弘 4 \\ Akihide TADA, Takayoshi INOUE, Yohei HONDA and Katsuhiro FURUMOTO \\ 1正会員 博（工） 長崎大学助教授 工学部社会開発工学科（８52-8521 長崎市文教町1-14） \\ 2学生会員 長崎大学大学院 工学研究科社会開発工学専攻（广852-8521 長崎市文教町1-14） \\ 3 学生会員 長崎大学大学院 生産科学研究科睘境システム工学専攻（テ852-8521 長崎市文教町1-14) \\ ${ }^{4}$ 正会員 工博 長崎大学教授 工学部社会開発工学科（厂852-8521 長崎市文教町1-14）
}

\begin{abstract}
This study concerns the evaluation on the discharge of inundating water flowed over a straight stair to underground space. First of all, survey at the entrances to the underground mall in JR Hakata Station is executed. Secondly, hydraulic experiments are carried out using a model of a straight stair. The obtained results are able to propose an empirical formula for evaluating the discharge to underground space. In particular, it is realized that the straight stair setting a footstep on the ground level's entrance has an effect on the mitigation of inundation flow in underground space.
\end{abstract}

Key Words : Inundation flow, underground space, straight stair, discharge, boundary condition

\section{1.はじめに}

わが国では，地下鉄，地下街および地下駐車場等と いった様々な形で地下空間の有効利用がなされており, 地下空間は今や日常生活にとって必要不可欠な空間と なっている. さらに，地下空間での防災対策は, 今まで 『防火』が中心であったため, そこでの水害対策はほと んど議論されておらず, 地下浸水の危険性さえも意識さ れてこなかった. このような背景の中，1999年6月には 福岡市で, 同年7月には東京都内で地下空間へ流れ込ん だ大量の汇監水によって溺死者を出すという惨事が発生 した. 言い換えれば，大都市部の地下空間が内水や外水 に伴う浸水に対して如何に脆いものであるかを露呈した といっても過言ではない.このような事態は, 豪雨時ば かりでなく, 高潮時や地震時にも生じる可能性が高いも のと予想される. したがって, 地下空間での河川水や海 水による浸水被害の予測, 浸水防御策, 避難誘導システ ムおよび復旧対策などに対して有用な情報を提供するた め, 地下空間への浸水の流入過程および伝播過程につい
て水理学的な解析を行っておくことは, 防災工学上も重 要な課題である.

一方, 地下空間への水の浸水過程に着目した既往の研 究は極めて数が少なく，1）洪水汇濫水の地下街への浸 入シミュレーション1)および2）大規模な高潮と洪水が 重畳した場合を想定し，地下空間における汇濫水の広が りについて水理学的な数值解析 ${ }^{2)}$ がなされているに過ぎ ない. これらの研究では, (1)平面二次元汇濫解析モデル を適用しているものの, 地下空間特有の管路・開水路共 存状態の遷移流れ ${ }^{3)}$ を考慮した解析はなされていないこ と, (2)地上開口部から地下街への流れが段落ちモデルで 説明できるものとみなして, 地下空間への流入流量を評 価していることが共通点である.

以上のようなことを考慮すれば, 地下空間における浸 水対策の一つとして, 洪水汇濫水に伴う浸水の流入 - 伝 播過程を水理学的に明らかにするとともに, 浸水予測シ ミュレーションを実施し, 地下空間での浸水に対する避 難誘導システムを確立することが早急に望まれる. 本研 究では, このような課題を解決するための第一段階とし 


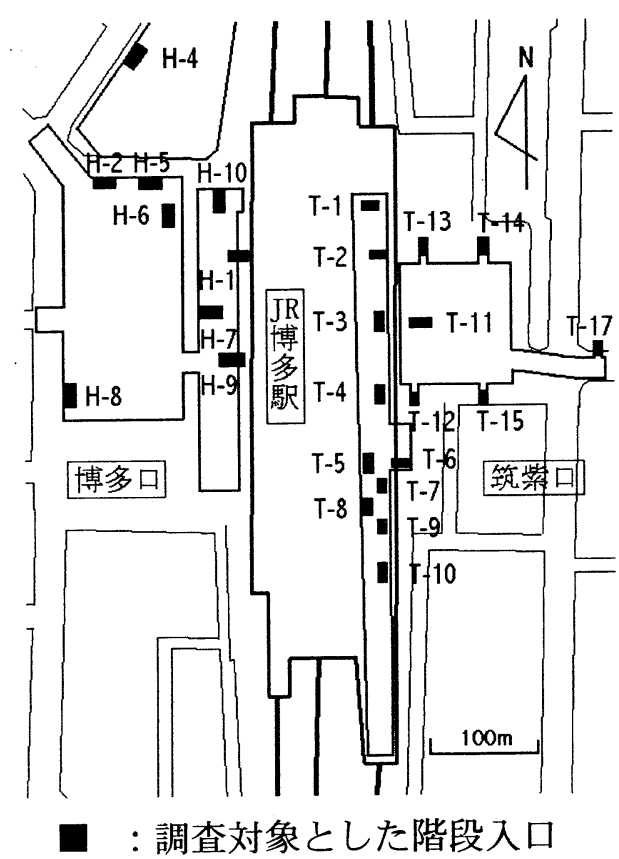

図一1 現地調査したJR博多駅周辺の階段入口

て，地下空間での浸水予測シミュレーションを実施する 際の境界条件となる階段入口の流入流量に着目し，その 水理特性に影響を及ぼすと予想される階段入口の構造形 式・各種諸元をJR博多駅地下街で現地調査している. つ いで，得られた現地調査の結果に基づき作製された階段 模型を用いて水理実験を行い，階段入口から地下空間へ 流入する流量の評価式を提案する. とくに，階段入口の 地上部に段差（ステップ）を設けた場合と設けない場合 の流入流量の比較から，地上部での段差の設置効果につ いても検討を加えている.

\section{2. 階段入口の構造形式に関する現地調査}

\section{（1）JR博多駅地下街を対象とした現地調查の概要}

1999年 6 月の福岡豪雨に伴って地下空間への浸水被害 が発生したJR博多駅を対象に, 地上部から地下街への通 路となっている筑紫口方面16 年, 博多口方面9ヶ所, 計25ヶ所の階段入口（図-1参照）で現地調査を1999年 12月9日に実施した ${ }^{4)}$. 調查方法は, 巻尺, 定規およびデ ジタルカメラを用いて, 地下街へ通じる階段入口の(1)幅 員, (2)階段の勾配, (3)地上部と地下街との高低差 (階 高），(4)階段ステップの高さ（けあげ高），(5)階段ス テップの幅 (踏み幅)，(6)階段総数，(7)踊り場の踏み幅, 8)段差（ステップ）の有無および(9)段差（ステップ）の 高さ・延長などを詳細に測量した.

\section{（2）現地調査結果およびその考察}

現地調査から得られた測量デー夕に基づいて，複雑な

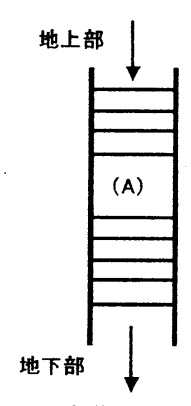

（i）直階段(2ブロック)

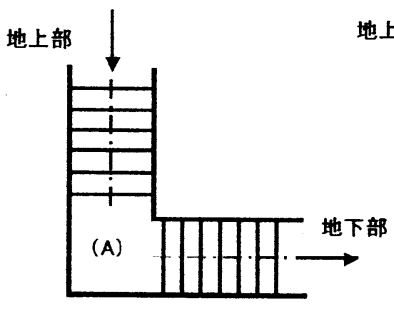

(iii）折れ階段

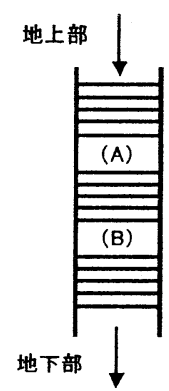

(ii) 直階段(3ブロック)

\section{図-2 階段入口の構造形式に関する分類}

構造を有する階段入口の形式について分類を試みた. そ の結果，図一2に示すような 4 つ基本パターンに大別 されることが分かった. すなわち，25ケ所の階段入口の うち, 直階段が13ヶ所（2ブロック：6ヶ所， 3 ブロッ ク：7ケ所）と最も多く, ついで折れ階段（右折れ：5ケ 所, 左折れ：1ヶ所）が6ヶ所, 折返し階段が4ヶ所で あった ${ }^{4)}$. 残り2ヶ所については, 特殊な形状（直階段と 螺旋階段がつながった形状および直階段の踊り場から他 の階段につながった形状）のため基本パターンから除外 した. なお，図一2（i ）に示す直階段は，地上部から踊 り場（A），踊り場（A）から地下部をそれぞれ1ブロッ クとみなし，2ブロックから構成されているものと考え た（図一3参照）。表一1は，図一3に定義されている 直階段（2ブロック）の場合の各諸元について整理した

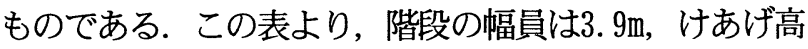
は $0.15 \mathrm{~m}$ ，踏み幅は $0.31 \mathrm{~m} ， 1$ ブロック当りの階段総数は

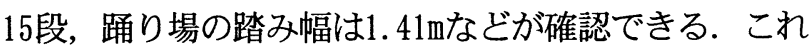
らの平均值は, 表-2に示す立体横断施設（例えば, 歩 道橋）の標準值 ${ }^{5}$ を満足している.

さらに, 図一4は1ブロック毎の階段落差 $F i$ と水平距 離 $L i$ との関係を示したものである. 図中には, 折れ階段 および折返し階段の場合のデータも同様な処理を施して 併記されている. 図より, 階段入口の形状に関係なくFi と $L i$ とは比例関係にあることが確認できる. なお，図中 の実線は，最小二乗法より算出した回帰式である．この 式より階段の平均勾配は $\theta=25^{\circ}$ となる ${ }^{4)}$.

また，写真一 1 に示すような地上部の階段入口に設け られた段差（ステップ）についても調査を行った. その 結果, JR博多駅地下街に向かう階段入口での段差（ス テップ）の設置率は44\%（11／25）と予測していたほど 大きくなかった. とくに, 段差（ステップ）が設けられ 


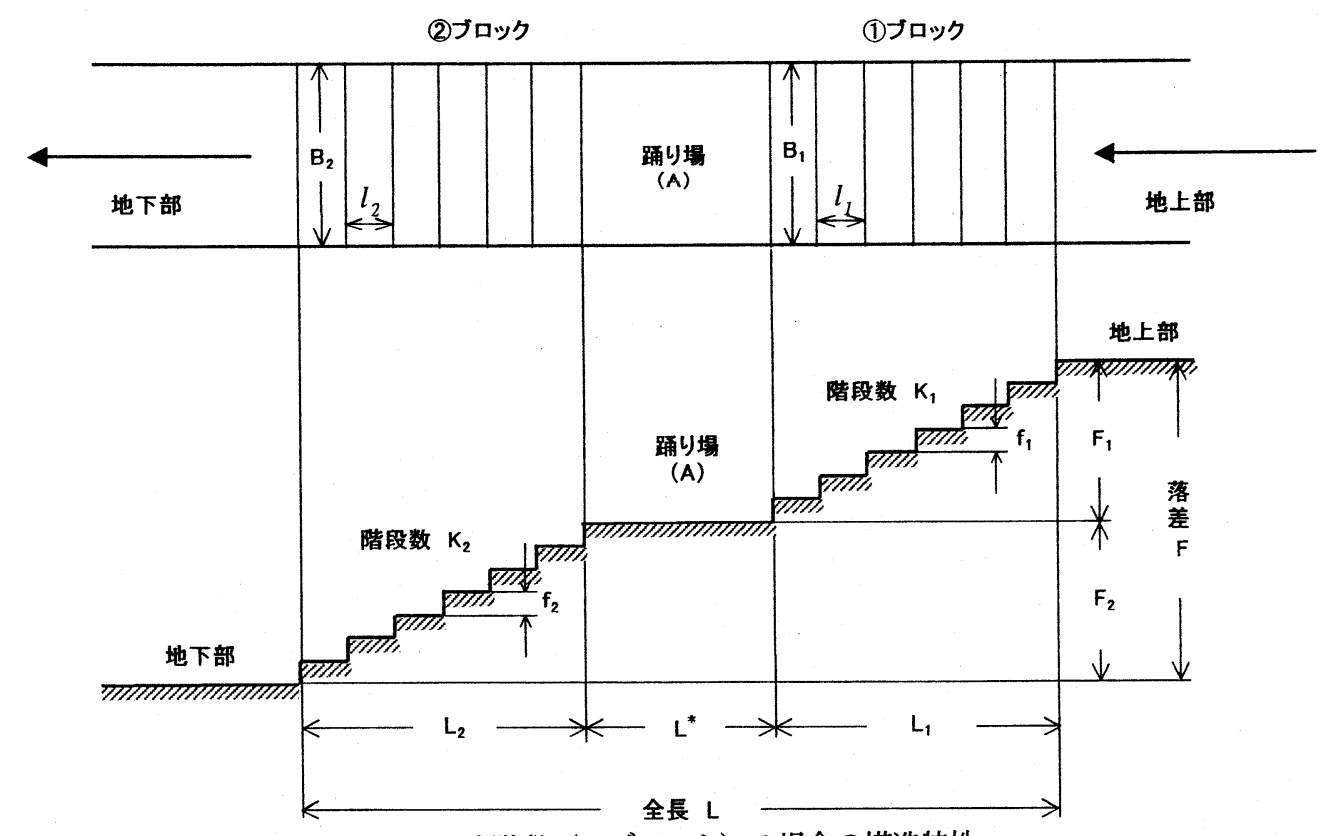

図-3 直階段（2ブロック）の場合の構造特性

表-1 現地調査した階段入口の諸元〔直階段（2ブロック）〕

(単位: $\mathrm{mm}$ )

\begin{tabular}{|c|c|c|c|c|c|c|c|c|c|c|c|c|c|c|c|c|}
\hline & \multicolumn{7}{|c|}{ (1)ブロック } & \multicolumn{7}{|c|}{ (2)ブロック } & \multirow[b]{2}{*}{$L^{*}$} & \multirow[b]{2}{*}{ 材質 } \\
\hline & $k_{1}$ & $f_{1}$ & $l_{2}$ & $F_{1}=f_{1} k_{1}$ & $L_{1}=\left(k_{1}-1\right) l_{1}$ & $F_{1} / L_{1}$ & $B_{1}$ & $k_{2}$ & $f_{2}$ & $l_{2}$ & $F_{2}=f_{2} k_{2}$ & $\mathrm{~L}=\left(\mathrm{k}_{2}-1\right) l_{2}$ & $F_{2} / L_{2}$ & $B_{2}$ & & \\
\hline$T-2$ & 15 段 & 146 & 326 & 2190 & 4564 & 0.4798 & $\frac{1}{4434}$ & 16段 & 148 & 326 & \begin{tabular}{|l|}
2368 \\
\end{tabular} & 4890 & 0.4843 & 4434 & 1516 & $\bar{A}$ \\
\hline$T-4$ & $17 \mathbf{E}^{-}$ & 151 & 315 & 2567 & 5040 & 0.5093 & 4520 & 14段 & 151 & 313 & 2114 & 4069 & 0.5195 & 4520 & 1515 & A \\
\hline$T-5$ & 16段 & 154 & 315 & 2464 & 4725 & 0.5215 & 4400 & 16段 & 146 & 317 & 2336 & 4755 & 0.4913 & 4400 & 1510 & A \\
\hline$T-8$ & $\begin{array}{l}16 \mathbf{E}^{\mathbf{2}} \\
\end{array}$ & 153 & 315 & 2448 & 4725 & 0.5181 & 3500 & 16 段 & 155 & 324 & 2480 & 4860 & 0.5103 & 3500 & \begin{tabular}{|l|}
1510 \\
\end{tabular} & A \\
\hline$T-9$ & $13 \mathbf{E}^{-}$ & 154 & 323 & 2002 & 3876 & 0.5165 & \begin{tabular}{|l|}
2960 \\
\end{tabular} & \begin{tabular}{|l|}
$19 \mathbf{E}^{-}$ \\
\end{tabular} & 148 & 326 & 2812 & 5865 & 0.4795 & \begin{tabular}{|l|}
2960 \\
\end{tabular} & \begin{tabular}{|l|}
1220 \\
\end{tabular} & $\bar{A}$ \\
\hline $\mathrm{H}-4$ & 18 段 & 154 & 300 & 2772 & 5100 & 0.5435 & 3778 & \begin{tabular}{|l|}
$18 \mathrm{E}^{-}$ \\
\end{tabular} & 154 & 300 & 2772 & 5100 & 0.5435 & \begin{tabular}{|l|}
3777 \\
\end{tabular} & \begin{tabular}{|l|}
1204 \\
\end{tabular} & $B$ \\
\hline 平均 & 16 段 & 152 & 316 & 2407 & 4672 & 0.5148 & 3932 & $17 \mathbf{E}^{2}$ & 150 & 318 & 2480 & $\overline{4923}$ & 0.5047 & 3932 & $\mid 1413$ & $\overline{-}$ \\
\hline
\end{tabular}

表-2 立体横断施設の標準值 ${ }^{5)}$

\begin{tabular}{|c|c|}
\hline 階段のけあげ高; $f$ & $15 \mathrm{~cm}$ \\
\hline 階段の踏み幅 ; $l$ & $30 \mathrm{~cm}$ \\
\hline 踊り場の踏み幅; $\mathrm{L}^{*}$ & $1.2 \mathrm{~m}$ 以上 \\
\hline
\end{tabular}

出典;日本道路協会

「立体横断施設技術基準·同解説」

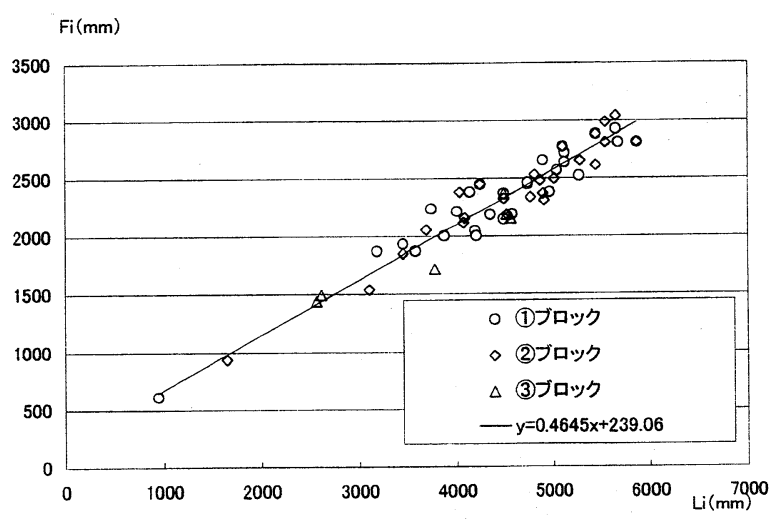

図-4 階段落差 $F i$ と水开距離 $L i$ との関係

ている階段入口は，すべて屋外に面していた．なお，段 差（ステップ）のけあげ高の平均值は0.11m, 段差（ス

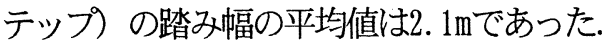

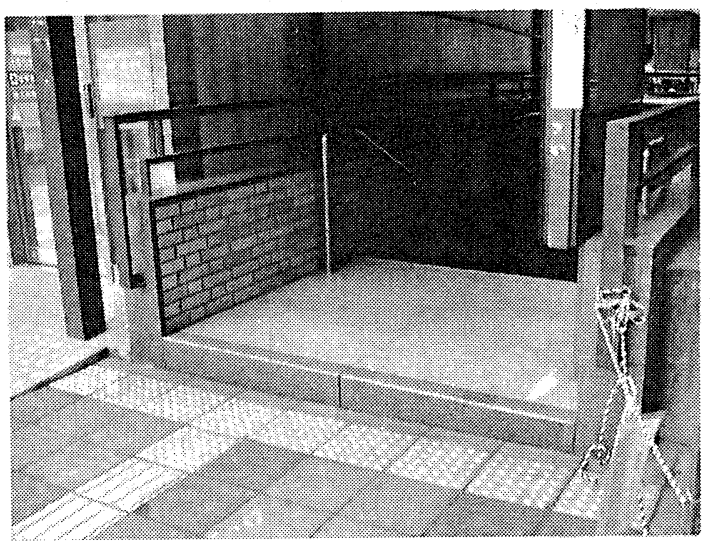

写真-1 地上部の階段入口に設けられた段差

\section{3. 階段入口から流入する流量の評価式の検討}

\section{（1）水理実験の概要}

構造形式として半数を占めた直階段を対象として地下 空間へ流入する流量の評価式を提案するため, フルード 相似則（縮尺 $1 / 15 ）$ を採用して図一5に示すようなア クリル製の階段模型を製作し，水理実験を行った ${ }^{6)}$ 。な お，模型の各諸元については表一3に示すとおりである. 実験は, 図一5のA点の水深 $\left(h_{5}\right)$ をパラメータとして 


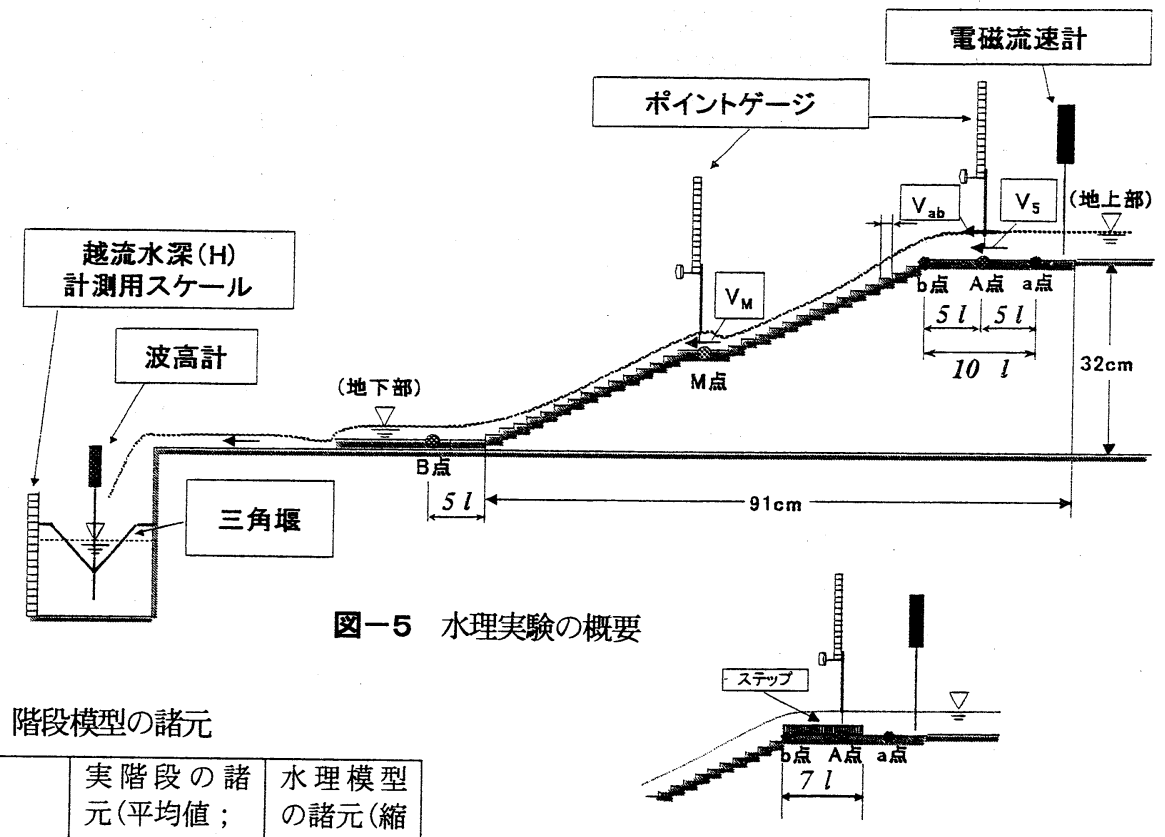

\begin{tabular}{|c|c|c|}
\hline & $\begin{array}{c}\text { 実階段の諸 } \\
\text { 元 (平均値 ; } \\
\text { JR博多駅) }\end{array}$ & $\begin{array}{l}\text { 水理模型 } \\
\text { の諸元 (縮 } \\
\text { 尺1/15) }\end{array}$ \\
\hline 階段入口の幅員（B) & $3.00 \mathrm{~m}$ & $20.0 \mathrm{~cm}$ \\
\hline 階段のけあげ高（f） & $0.15 \mathrm{~m}$ & $1.0 \mathrm{~cm}$ \\
\hline 階段の踏み幅（l） & $0.30 \mathrm{~m}$ & $2.0 \mathrm{~cm}$ \\
\hline 1 ブロック当りの階段数 & 15段 & 15段 \\
\hline 踊り場の踏み幅 $\left(L^{*}\right)$ & $1.50 \mathrm{~m}$ & $10.0 \mathrm{~cm}$ \\
\hline 段差(ステップ)のけあげ高 & $0.11 \mathrm{~m}$ & $0.8 \mathrm{~cm}$ \\
\hline 段差 $($ 行ップ )の踏み幅 & $2.10 \mathrm{~m}$ & $14.0 \mathrm{~cm}$ \\
\hline
\end{tabular}

\section{Run-1, Run-3}

(1)A点の水深 $h_{5}$ を変化させて $V_{5} 、 Q_{D}, H$ 計測

直角三角堰を越流する流量Q $Q_{D}$ は、ストップウォッチとメスシリンダーを 用いて直接測定

\section{直角三角堐の流量公式}

$Q=\frac{8}{15} C_{*} \sqrt{2 g} H^{5 / 2}$

$Q$; 直角三角堰の越流量 $\left(\mathrm{cm}^{3} / \mathrm{s}\right) ， \mathrm{C}_{*} ;$ 流量係数

$\mathrm{g}$; 重力加速度 $\left(980 \mathrm{~cm} / \mathrm{s}^{2}\right), \mathrm{H}$; 直角三角堰の越流水深 $(\mathrm{cm})$

(2)計測された $Q_{D}$ とHを(1)式に代入し、最小二乗法を用いてC $A$ 点での平均断面流速 $V_{5}$ (2点法)より流入流量 $Q_{C V}$ を算定

\section{(3)地下空間へ流入する流量の評洒式}

$$
Q=C_{*}^{\prime} B h_{5}{ }^{a}
$$

$\mathrm{C}_{*}^{\prime}$; 直階段の流量係数，B; 階段の幅員 $(\mathrm{cm})$

$h_{5} ; A$ 点での水深 $(\mathrm{cm}), a ;$ 定数

上式（(2)式)に計測した $h_{5}, Q_{D}$ を代入し、最小二乗法よりC.'、aを算出

Run-2、Run-4

(4) A点の水深 $\left(\mathrm{h}_{5 *}\right)$ を変化させて水面形、三角堭の越流水深 $\left(\mathrm{H}_{*}\right)$ ，

踊り場 $M$ 点の水深 $\left(h_{M}\right)$,地下部 $B$ 点の水深 $\left(h_{B}\right)$ を計測

\section{(5)トレーサーによる流下時間の計測}

(6) H*およびRun-1(Run-3)の実験結果より特定したC、を(1)式へ代入 し、越流量 $Q_{\mathrm{c}}$ を算出

(7) $\mathrm{h}_{5 *}$ を(2)式に代入して流入流量Qを算定

図-6 流量評価式の誘導フローチャート
表-4 流量評価式(2)の流量係数 $C_{*}{ }^{\prime}$ と定数 $a$

\begin{tabular}{|c|c|c|c|}
\hline 実験欠-ス名 & $C_{*}{ }^{\prime}$ & $a$ & 段差の設置 \\
\hline Run-1 & 20.98 & 1.88 & なし \\
\hline Run-3 & 30.55 & 1.38 & あり \\
\hline
\end{tabular}

流量 $Q\left(\mathrm{~cm}^{3} / \mathrm{s}\right)$

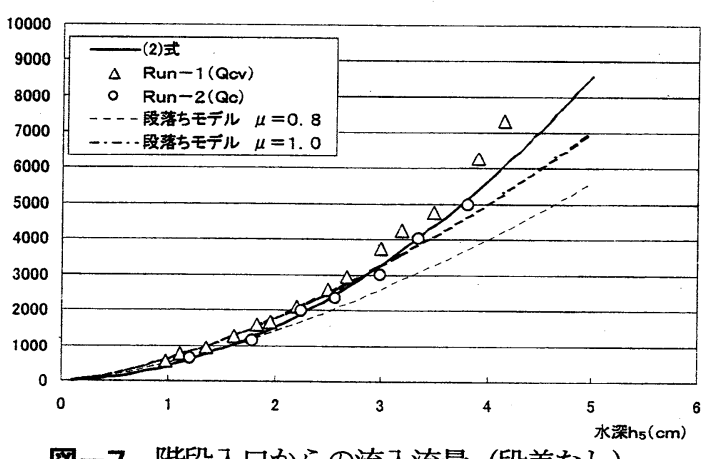

図-7 階段入口からの流入流量（段差なし）

変化させ, 流れが定常になったことを確認した後, (1)階 段部へ流入する流量 $(Q)$, (2)A点の断面平均流速 $V_{5}(2$ 点法), (3)地上部 ( $b$ 点〜 $a$ 点の区間) の水面形などにつ いて三角堰, 電磁流速計およびポイントゲージ等を用い て計測した. とくに，階段入口の地上部に段差（ステッ プ）を設けない場合(Run-1, Run-2) と段差（ステップ） を設けた場合 (Run-3, Run-4) の比較を通して，地上部で の段差の設置効果についても検討を加えた.

\section{（2）水理実験結果およびその考察}

図一6に示すフローチャートに従って，階段入口から 地下部へ流入する流量Qの評価式を誘導した. その結果, 表一4のように(2) 式の流量係数 $C_{*}$ ' および定数 (べき乗) aが求まった ${ }^{6)}$.

図一7は, 地上部A点の水深 $h_{5}$ と(2) 式で評価される流 量 $Q$ との関係（Run - 1, 段差なし）を太線で示したもの

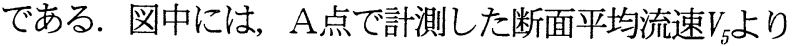


表-5 実験ケースの水理量（Run-2およびRun-4）

\begin{tabular}{|c|c|c|c|c|c|c|c|}
\hline ケース名 & $\begin{array}{c}\text { 越流水深 } \\
\mathrm{H}_{*}(\mathrm{~cm})\end{array}$ & $\begin{array}{c}\text { 点の水深 } \\
\mathrm{h}_{5 *}(\mathrm{~cm})\end{array}$ & $\begin{array}{c}\text { 越流量 } \\
\mathrm{Q}_{\mathrm{c}}\left(\mathrm{cm}^{3} / \mathrm{s}\right)\end{array}$ & $\begin{array}{c}\mathrm{M} \text { 点の水深 } \\
\mathrm{h}_{\mathrm{M}}(\mathrm{cm})\end{array}$ & $\begin{array}{c}\mathrm{B} \text { 点の水深 } \\
\mathrm{h}_{\mathrm{B}}(\mathrm{cm})\end{array}$ & $\begin{array}{c}\text { レイルズ数 } \\
\mathrm{Re}=\mathrm{U}_{5} \mathrm{~h}_{5 *} / \nu\end{array}$ & $\begin{array}{c}\text { 流入流量 } \\
\mathrm{Q}\left(\mathrm{cm}^{3} / \mathrm{s}\right)\end{array}$ \\
\hline Run-2-1 & 4.26 & 1.21 & 624.4 & 0.44 & 0.41 & 2,383 & 600.4 \\
\hline Run-2-2 & 5.43 & 1.79 & $1,145.3$ & 0.57 & 0.51 & 4,371 & 1253.7 \\
\hline Run-2-3 & 6.77 & 2.25 & $1,987.9$ & 0.85 & 0.69 & 7,587 & 1927.3 \\
\hline Run-2-4 & 7.22 & 2.57 & $2,334.9$ & 0.89 & 0.74 & 8,912 & 2474.6 \\
\hline Run-2-5 & 7.98 & 3.00 & $2,798.9$ & 1.12 & 1.17 & 11,446 & 3310.0 \\
\hline Run-2- & 8.97 & 3.36 & $4,017.1$ & 1.45 & 1.28 & 15,332 & 4095.9 \\
\hline Run-2-7 & 9.77 & 3.81 & $4,973.6$ & 1.73 & 1.84 & 18,983 & 5187.7 \\
\hline \hline Run-4-1 & 2.42 & 0.62 & 144.3 & 0.55 & 0.58 & 551 & 315.9 \\
\hline Run-4-2 & 3.30 & 0.91 & 313.4 & 0.50 & 0.55 & 1,196 & 536.4 \\
\hline Run-4-3 & 5.66 & 1.53 & $1,207.5$ & 0.70 & 0.56 & 4,609 & 1098.8 \\
\hline Run-4-4 & 6.76 & 2.03 & $1,882.4$ & 0.83 & 0.83 & 7,185 & 1623.3 \\
\hline Run-4-5 & 7.70 & 2.76 & $2,606.6$ & 0.95 & 1.02 & 9,949 & 2480.3 \\
\hline Run-4-6 & 8.55 & 3.35 & $3,386.6$ & 1.14 & 1.20 & 12,928 & 3240.4 \\
\hline
\end{tabular}

レイノルズ数 $(R e) ; \mathrm{U}_{5}=\mathrm{Q}_{\mathrm{c}} /\left(\mathrm{Bh}_{5 *}\right), \quad \nu=1.310 \times 10^{-2} \mathrm{~cm}^{3} / \mathrm{s}\left(10^{\circ} \mathrm{C}\right)$

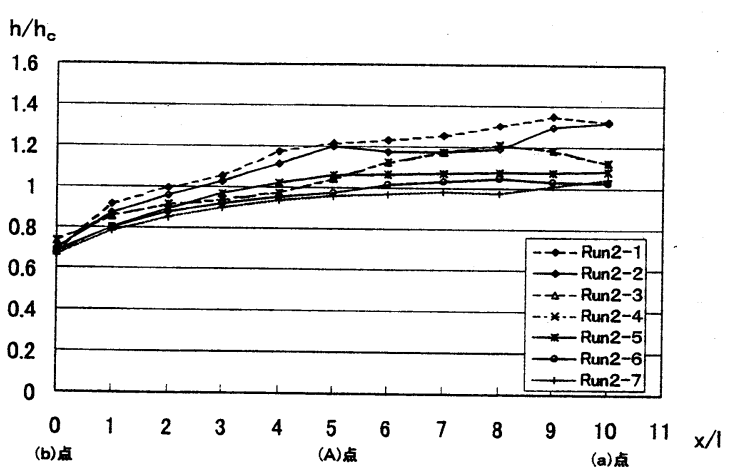

図-8 地上部b点〜 a点間の水面形（段差なし）

算定された $Q_{c v}(\triangle)$ と $(1)$ 式より求めたRun- $2 の Q_{c}(\bigcirc)$ が プロットされている. $Q_{c v}$ の值は，すべての実験ケース で(2)式の值よりも大きくなっている. これはA点の断 面平均流速 $V_{5}$ を流心軸上で2点法によって算出したため, $Q_{c v}$ を過大評価しているものと考えられる. 一方， $Q_{c}$ は (2)式よりも小さいことが分かる. しかし，両者は(2)式 の曲線を挟んで分布しており，平均的には (2) 式の妥当 性が確認できる. さらに, 図中には段落ちモデル ${ }^{1)}$ に流 量係数 $\mu=0.8$ および $\mu=1.0$ を与えた場合の流量がそれ ぞれ細破線および太破線で示されている. A点の水深 $h_{5}$ が3cm以下の場合には, 流入流量Qをここで提案する(2) 式から算出しても段落ちモデルで求めても大差がないこ とが明らかとなった ${ }^{6)}$. また, 表一5に示す $Q_{c}$ および $Q$ の比較より，(2) 式は, A点の水深 $h_{5}$ が, $h_{5}<1 \mathrm{~cm}$ お び $h_{5}>4 \mathrm{~cm}$ の範囲では適用が難しいものと判断される.

一方, $1 \mathrm{~cm} \leqq h_{5} \leqq 4 \mathrm{~cm}$ 範囲内では, ほぼ $0.95<Q / Q_{c}<$ 1.05の関係が成立していることも確認できる. なお, 既 往の研究では段落ち部の流量を次式より算定している77).

$$
Q=C B h_{f}^{3 / 2}
$$

但し, $h_{f}$; 段縁の水深, $C$; 流量係数, $B$; 水路幅である. 本研究では, 洪水汇濫に伴う地下空間への浸水の予測シ ミュレーションを実施する上で重要となる境界条件を明 らかにするという主な目的のため, 流入流量 $Q$ を評価す

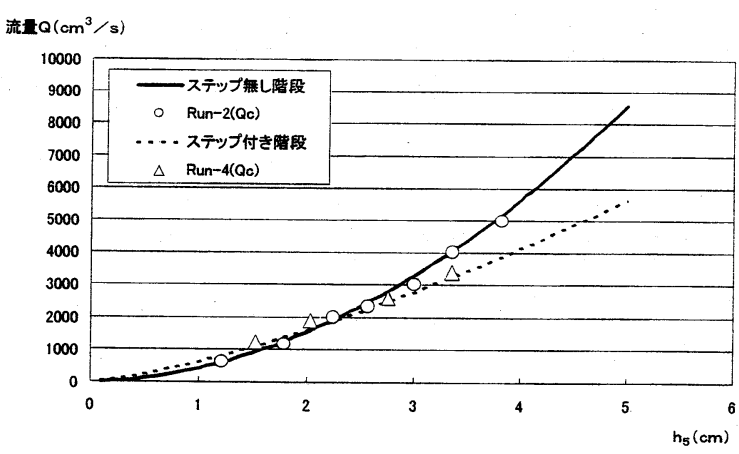

図-9 流入流量に及ぼす段差 $($ スデップ )の影響

る際に必要な水深（越流水深； $h_{*}$ ) を『段縁 ( $\mathrm{b}$ 点)から 上流側へ5 $l$ の点』でしか測定していない。一般的に, 数值シミュレーションを実施する際に用いられる計算格 子の水深は, 格子サイズ内で平均化され, 格子中央部で 定義されることが大半である. ここでも，水理実験に際 して, 計算格子のサイズを階段入口の幅員 $(B)$ と同じ程 度, すなわち $10 l$ と考えた. このため, 格子中央は $\mathrm{b}$ 点 から上流側へ $5 l$ の位置となり, A点が選択されたので ある. さらに, 既往の研究に基づけば7), 流量の増加と ともに限界水深の発生位置が変化するので, それに伴っ て越流水深 $\left(h_{\ddagger}\right)$ の測定位置を変化させる必要がある. したがって, 流量評価式に採用する越流水深 $h_{\boldsymbol{q}}$ の測定位 置については，今回採用した $h_{5}$ 以外にも $h_{6}$ や $h_{7}$ 等の妥当 性について検討する余地が残されている.

図一8は, 地上部の階段端部 $\mathrm{b}$ 点（段縁）から上流側 へ取った距離 $x$ と $h / h_{c}\left(h_{c}\right.$ : 限界水深) との関係を示した ものである. 各ケースとも $h / h_{c}$ の值は上流側に向かうほ ど増加している. また, 流入流量Qの増加（表－5参 照）とともに同一測点での $h / h_{c}$ の值が減少傾向にある. これは, 流入流量Qの増加に伴って, b 点 (段縁) 近傍に 出現する射流区間 $\left(h / h_{c}<1.0\right)$ が上流側へ拡大していく ものと解釈できる. なお, b点 (段縁) より下流側の階 段直上の流れはすべて射流であり, $h_{5} \geqq 3 \mathrm{~cm}$ の条件下で流 


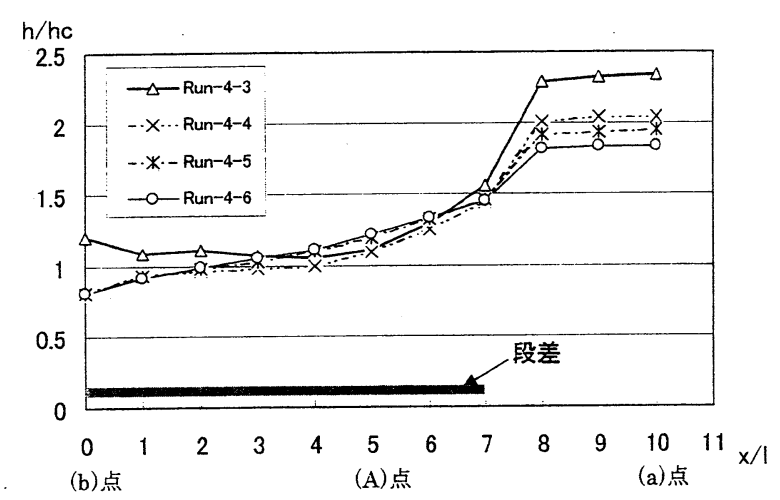

図-10 地上部b点〜 $\mathrm{a}$ 点間の水面形 (段差あり)

況が大きく変化する. すなわち, 踊り場の段縁から流水 が地下部に向けてジャンプするとともに, 踊り場の段縁 から下流側に 5 6段の範囲で流水下が空洞となることも 明らかとなった。

図一9は, Run- 2 およびRun- 4 の場合の $Q_{c}$ と表一4に 示す2つの流量評価式とを併記して, 比較したものであ る. A 点の水深 $h_{5}$ が $2 \mathrm{~cm}$ を超えるあたりから, 同一水深 でも段差（ステップ）を設置している場合の方が階段へ 流入する流量は小さくなることが分かる. 図一10は, 段 差（ステップ）を設置している場合の $\mathrm{b}$ 点(段縁)から上 流側へ取った距離 $x$ と $h / h_{c}\left(h_{c}\right.$ : 限界水深）との関係を示 したものである. 図より, (1)段差の存在に伴って $b$ 点〜 $\mathrm{a}$ 点区間の流れの大半が常流となっていること, さらに, (2)段差が設置されていない場合より $h / h_{c}(>1.0)$ の值 が大きくなっていることが確認できる.これらが, 図一 9の流入流量の評価式(段差がある場合)において同一水 深でも流量が小さくなった理由であると考えられる.

図一11は，階段の踊り場 $\mathrm{M}$ 点および地下部B点での平 均流速 $V_{M}\left(=Q_{C}\left(B h_{M}\right)\right)$ および $V_{B}\left(=Q_{C}\left(B h_{B}\right)\right)$ とA 点水深 $h_{5}$ との関係を示したものである. 水深 $h_{5}$ の増加と

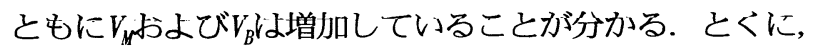
$h_{5}=3.0 \mathrm{~cm}$ （実物大では $h=0.45 \mathrm{~m}$ ）の時, 階段の踊り場 $\mathrm{M}$ 点の平均流速 $V_{M}$ は $117.0 \mathrm{~cm} / \mathrm{s}$ となった. この流速を実 物大の流速に換算すると $4.53 \mathrm{~m} / \mathrm{s}$ であり, 歩行者が階段 部を通行できるような流速ではないものと判断される. なお，本研究は，「定常流れで階段部に流入する流量 $Q$ が，下流水路の直角三角堰を越流する流量 $Q_{c}$ に等し い」という前提条件に基づいて実施されている.このた

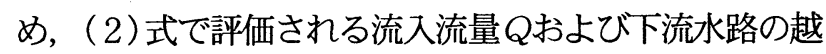
流量 $Q_{C}$ の精度については, 越流水深の測定器の精度お よび流量係数 $C_{\ddagger}$ の算定法に関する精度を詳細に検討し, その後に考察する必要があるものと判断される.

\section{4. おわりに}

本研究では, 地下空間での浸水予測シミュレーション

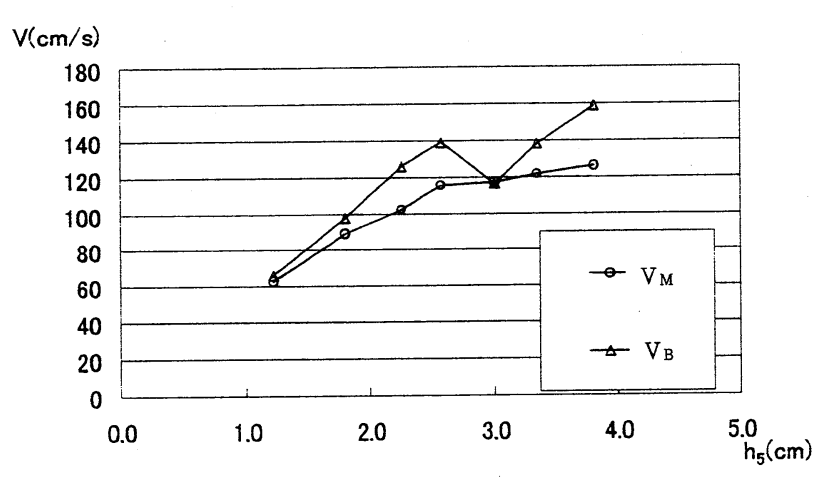

図一11 平均流速 $V_{4}$ および $V_{B}$ と水深 $h_{5}$ との関係

を実施する際の境界条件となる階段入口から地下空間へ 流入する流量に着目し, その定量的な評価式について検 討を加えた. まず，地下空間へ流入する流量の水理特性 に影響を及ぼすと予想される階段入口の構造形式・各種 諸元について, JR博多駅を対象に現地調査を実施した. 次いで, 構造形式の半数を占めた直階段を対象とした水 理実験を行い，階段入口から地下空間へ流入する流量の 評価式を提案した. その結果, 流入流量は地上部 $\mathrm{A}$ 点の 水深 $h_{5}$ の指数形式（図一6の (2) 式) で評価できること が明らかとなった. さらに, 階段入口の地上部に段差

（ステップ）を設けた場合と設けない場合の流入流量の 特性を比較した. その結果, 地上部の階段入口に設置さ れている段差は，少なくとも地下空間での浸水被害を軽 減もしくは遅延させる効果を有していることが水理学的 に確認された.

\section{参考文献}

1）高橋 保・中川一・野村 出 : 洪水汇濫に伴亏地下街浸水 のシミュレーション, 京都大学防災研究所年報, 第33号 B-2, pp. 427 442, 1990.

2）井上和也・中川一・戸田主一・满田敏夫: 地下空間へひ 汇濫浸水の解析, 地下空間シンポジウム論文・報告集, 第2 巻, 土木学会, pp. 95 102, 1997.

3）細田 尚・井上和也・多田彰秀・北原政宏: 管路 - 開水路 流れ境界面の伝播を考慮した非定常流の数值解析法, 京都大 学防災研究所年報, 第36号 B-2, pp. 593 605, 1993.

4) 井上啓由・本田洋平·木村克志·多田彰秀: 階段入口から地 下空間へ流入する流量の評価に関する考察, 平成 11 年度士木 学会西部支部研究発表会講演概要集, 第2分冊 II -34 , pp. 224 225, 2000.

5）（社）日本道路協会：立体横断施設技術基準 - 同解説, pp. 31 32, 1979.

6) 本田洋平・井上啓由.木村克志·多田彰秀: 階段入口から地 下空間へ流入する流量の評価式について, 土木学会第 55 回年 次学術講演会講演概要集, 第2分野, II-197, pp. 394 395, 2000.

7）土木学会編：水理公式集，昭和60年度版, p. $288,1985$.

(2000.10.2受付) 